\title{
Survival of Sprouting Shrubs Following Summer Fire: Effects of Morphological and Spatial Characteristics
}

\author{
Emily C. Dacy ${ }^{1}$ and Timothy E. Fulbright ${ }^{2}$ \\ Authors are ${ }^{1}$ Graduate Research Assistant, Ecosystem Science and Management, Texas A\&M University, College Station, TX 77843, USA; \\ ${ }^{2}$ Regents Professor and Meadows Professor in Semiarid Land Ecology, Caesar Kleberg Wildlife Research Institute, Texas AひM University-Kingsville, \\ Kingsville, TX 78363, USA.
}

\begin{abstract}
Efficacy of fire in reducing shrub density is low in plant communities where most woody plants resprout from stem bases and crowns following fire. Our objective was to determine the relationship of shrub mortality and recovery from summer fire to prefire shrub structural characteristics. A randomized, complete block design with two treatments (burned and control) and three blocks was used in the experiment. Within each block and treatment combination, we randomly selected 40 individuals each of brasil (Condalia hookeri M. C. Johnst.), huisache (Acacia farnesiana [L.] Willd.), and spiny hackberry (Celtis ehrenbergiana [Klotzsch] Liebm.). We estimated height, canopy diameter, number of stems, stem diameter, and distance to the nearest shrubs before ignition of fires. Fires were ignited during July and August 2001. Survival, sprout number, height, and total plant height were estimated 47-52 wk postburn. Mortality of brasil was 26 times greater on burned sites than on control sites, but mortality of huisache and spiny hackberry was negligible. Mortality of brasil varied from $0 \%$ to $68 \%$ among blocks. Postburn height and number of sprouts increased with preburn shrub height and number of stems, indicating that longer intervals of time between fires that allow shrub growth facilitate more rapid postfire recovery. Factors other than the preburn shrub structural characteristics we measured appear to influence postfire shrub survival most strongly, although these characteristics are useful in predicting postfire sprout production and shrub height.
\end{abstract}

\section{Resumen}

La eficacia del fuego en reducir la densidad arbustiva es baja en las comunidades de plantas donde las plantas leñosas pueden rebrotar de la base del tallo y la corona después del fuego. Nuestro objetivo fue determinar la relación entre la mortalidad y la recuperación de los arbustos desde el fuego de verano y las características estructurales de arbusto anterior al fuego. Para el estudio se utilizó un diseño de bloques completos al azar con dos tratamientos (quema y control) y tres repeticiones. Dentro de cada combinación de bloque y tratamiento se seleccionaron al azar 40 plantas de brasil (Condalia hookeri M. C. Johnst.), huizache (Acacia farnesiana [L.] Willd.), y granjero (Celtis ehrenbergiana [Klotzsch] Liebm.). Nosotros estimamos la altura, el diámetro de la copa, el número de tallos, el diámetro de los tallos, y la distancia al arbusto más cercano antes de la ignición de los fuegos. Las quemas se realizaron durante Julio y Agosto del 2001. Entre las 47 y 52 semanas después de la quema se estimó la sobrevivencia, el número de rebrotes, la altura, y la altura total de las plantas. La mortalidad de brasil fue 26 veces más alta en los sitios quemados que en los sitios control, sin embargo, la mortalidad de huisache y granjero fue insignificante. La mortalidad de brasil varió de $0 \%$ a $68 \%$ entre bloques. La altura y el número de rebrotes después de la quema se incrementaron con el incremento en la altura y el número de tallos antes de la quema, lo cual indica que los intervalos más largos de tiempo entre quemas que permiten el crecimiento de los arbustos facilitan una recuperación más rápido después del fuego. Otros factores además de la las características estructurales del arbusto que se evaluaron antes de la quema parecen tener una influencia más fuerte en la sobrevivencia de las plantas después del fuego, aunque estas características no son útiles para predecir la producción de rebrotes y altura de arbusto después del fuego.

Key Words: Acacia farnesiana, Celtis ehrenbergiana, Condalia hookeri, prescribed burning, south Texas

\section{INTRODUCTION}

Woody plant density has increased substantially in rangelands of southwestern United States during the past $200 \mathrm{yr}$ (Van Auken 2000). In southern Texas, fires ignited by native Americans or by natural causes possibly occurred at 1-6-yr intervals during pre-Columbian times (Frost 1998). These

Research was funded by the Welder Wildlife Foundation and Ed Rachal Foundation.

At the time of the research, Dacy was Graduate Research Assistant, Caesar Kleberg Wildlife Research Institute, Texas A\&M University-Kingsville, Kingsville, TX 78363, USA.

Correspondence: Timothy E. Fulbright, Caesar Kleberg Wildlife Research Institute, Texas A\&M University_Kingsville, Kingsville, TX 78363, USA. Email: timothy.fulbright@tamuk.edu

Manuscript received 8 May 2008; manuscript accepted 22 November 2008. periodic fires may have been a factor in maintaining grasslands, and cessation of these periodic fires may have in part led to replacement of grassland by thorn scrub (Fulbright 2001). Reducing the canopy cover of woody plants may increase herbaceous forage available to livestock and improve habitat for game species such as white-tailed deer (Scifres 1980; Fulbright and Ortega-S. 2006). Use of fire to reduce brush is less expensive than mechanical or chemical methods. Understanding plant morphological or spatial distribution characteristics related to greater postfire mortality or reduced postfire recovery may help land managers develop more effective approaches to using fire to reduce shrub densities.

Woody plant species in ecosystems frequented by fire often have the ability to resprout from dormant buds on underground organs 
after the plant has been top killed (Drewa et al. 2002; Pausas et al. 2004). Ability of woody plants to resprout after fire is an important factor allowing them to persist following recurrent fires (Scifres 1980; Bond and Midgley 2001). Efficacy of prescribed fire in reducing shrub density is low in ecosystems where most woody plants are capable of resprouting. Effect of season of burning on sprout production following fire varies among woody plant species (Drewa et al. 2002; Konstantinidis et al. 2005; Abella and Fulé 2008). Resprouting of shrubs in long-leaf pine (Pinus palustris Mill.) savannas, for example, tended to be greater following dormantseason fires than following growing-season fires, but results varied depending on habitat (Drewa et al. 2002). Postfire precipitation was an important determinant of resprout development in kermes oak (Quercus coccifera L.; Konstantinidis et al. 2005).

In addition to presence of subterranean regenerative organs, plant size (height and stem diameter), fuel load, and shrub location relative to other shrubs possibly affect shrub survival following fire (Flinn and Wein 1977; Flinn et al. 1992). Fire resistance also depends on bark properties, growth rate between fires, and other growth factors that vary across species (Gignoux et al. 1997).

Effects of season of burning on mortality of woody plants are variable and depend on a variety of factors, including ambient temperature and humidity, wind speed, soil moisture, fuel loads, fuel heterogeneity, abundance of live herbaceous fuel, and plant carbohydrate reserves (Owens et al. 2002; Sparks et al. 2002; Ruthven et al. 2003; Abella and Fulé 2008). Growing-season fires have the potential to damage shrubs more than cool-season fires because warm ambient temperatures result in greater fire intensity, and physiological damage to plants may be more likely when plants are actively growing (Ansley and Taylor 2004; Taylor 2007). Huisache (Acacia farnesiana [L.] Willd.) plants burned during the middle or at the end of the growing season had reduced stem elongation the first month after leaf emergence in spring (Rasmussen et al. 1983). Shrub species may vary in their response to fire. Percent frequency of brasil (Condalia hookeri M. C. Johnst.), for example, was reduced by fire applied in September, whereas frequency of huisache and spiny hackberry (Celtis ehrenbergiana [Klotzsch] Liebm.) was not (Box et al. 1967).

We selected three shrub species for study that are ubiquitous dominant or subdominant components of Tamaulipan scrub communities in Texas and northern Mexico. All three species are capable of sprouting from crowns and stem bases: brasil, huisache, and spiny hackberry (McLendon 1991). We tested the hypothesis that prefire structural characteristics, position relative to other shrubs, and basal fine fuel load surrounding a shrub influences shrub survival and recovery following summer prescribed fire. We predicted 1) shrub mortality increases and recovery of regrowth following fire decreases with decreasing prefire plant height, canopy diameter, number of basal stems, stem diameter, and proximity to neighboring shrubs; and 2) mortality increases and recovery following fire decreases with increasing fine fuel biomass at the base of the shrub.

\section{METHODS}

\section{Study Areas}

Study sites were on the Rob and Bessie Welder Wildlife Refuge (WWR; lat $28^{\circ} 6^{\prime} \mathrm{N}$, long $97^{\circ} 25^{\prime} \mathrm{W}$ ) and the Roche-Thompson
Division of McFaddin Enterprises (RTD; lat $28^{\circ} 23^{\prime} \mathrm{N}$, long $\left.97^{\circ} 60^{\prime} \mathrm{W}\right)$ in southern Texas. Climate of the area is humid subtropical, with hot summers and cool winters. Soil of WWR is a fine, smectitic, hyperthermic Sodic Halplustert of the Victoria series of clays (Soil Survey Staff, Natural Resources Conservation Service, US Department of Agriculture 2008). Mean annual rainfall (1956-2002) was $899 \mathrm{~mm}$ at the WWR, with peaks in May-June and September (WWR Records 2002, unpublished). Elevation is about $12 \mathrm{~m}$ above sea level and slope gradients are $<1 \%$. Soils of RTD are fine-loamy, mixed, superactive, hyperthermic Typic Argiustolls of the Orelia series. The dominant vegetation community of both study sites is a mesquite (Prosopis glandulosa Torr.)-mixed-grass community (Drawe et al. 1978). Dominant grasses include Texas wintergrass (Nassella leucotricha [Trin. \& Rupr.] Pohl), plains bristlegrass (Setaria leucopila [Scribn. \& Merr.] K. Schum.), and vine mesquite (Panicum obtusum Kunth). All plant names follow US Department of Agriculture, Natural Resources Conservation Services (2008).

Previous management practices differed at the two locations. The RTD study area was chained in 1990, whereas the WWR study area was burned in January 1996. The WWR supports about $2.5 \mathrm{ha} \cdot$ animal unit $(\mathrm{AU})^{-1}$, and RTD runs $1.2 \mathrm{ha} \cdot \mathrm{AU}^{-1}$. Cattle grazing was deferred on WWR for 11 mo before burning and cattle grazing was deferred for 4 mo on RTD. Estimated white-tailed deer (Odocoileus virginianus Raf.) densities were $4 \mathrm{ha} \cdot$ deer $^{-1}$ at WWR and $10 \mathrm{ha} \cdot$ deer $^{-1}$ at RTD during 20012002. During the study, one control experimental unit at WWR was grazed by cattle at $0.18 \mathrm{AU} \cdot \mathrm{ha}^{-1}$ in the pasture for $4 \mathrm{mo}$. The other control experimental unit at WWR was stocked between 0.05 and $0.07 \mathrm{AU} \cdot \mathrm{ha}^{-1}$ from 1 June 2001 to 1 March 2002. The burned experimental units at WWR were not grazed during the study. Cattle grazed the burned experimental units at the RTD for 2 mo in spring following the burn.

\section{Experimental Design}

We used a randomized, complete block experimental design with two treatments (burned vs. not burned), three shrub species, and three spatially separate blocks (two blocks on WWR and one block on RTD) to test the predictions. Each of the two blocks at WWR consisted of 202-ha burned experimental units and adjacent areas used as experimental controls that were not burned. The two blocks on WWR were $>200 \mathrm{~m}$ apart. The block at RTD consisted of a 404-ha burned experimental unit and an adjacent control area of similar size. A $480 \times 300 \mathrm{~m}$ (14.4-ha) sampling area was delineated within each burned experimental unit and adjacent control (not burned) experimental unit in each of the three blocks before burns were conducted. Sampling areas were placed near the center of burned experimental units so that they were in the path of head fires. Within each sampling area in each treatment and block combination, 40 evenly spaced points $60 \mathrm{~m}$ apart were permanently marked. The nearest shrub of each of the three target species within $30 \mathrm{~m}$ of the point was chosen in a randomly selected cardinal direction at each point.

\section{Prefire Shrub Measurements}

Study shrubs in each experimental unit were marked before the fire with a numbered metal tag affixed by wire around a basal 
Table 1. Fuel and weather conditions for prescribed burns conducted 13 July 2001 in two blocks at the Welder Wildlife Refuge (WWR 1 and WWR 2) in San Patricio County and on 25 August 2001 in one block at the Roche-Thompson Division (RTD) in Bee County, Texas.

\begin{tabular}{|c|c|c|c|}
\hline \multirow[b]{2}{*}{ Characteristic } & \multicolumn{3}{|c|}{ Site (Block) } \\
\hline & WWR 1 & WWR 2 & RTD \\
\hline $\begin{array}{l}\text { Basal fuel load (standing herbaceous } \mathrm{m} \\
\text { shrubs) } \pm \mathrm{SE}\left(\mathrm{kg} \cdot \mathrm{ha}^{-1}\right), n=120\end{array}$ & $5952 \pm 371$ & $3280 \pm 274$ & $1921 \pm 149$ \\
\hline $\begin{array}{l}\text { Percent dry matter of basal fuel load } \pm \\
\text { measured within } 1 \text { wk preburn }\end{array}$ & $71.4 \pm 1.1$ & $71 \pm 1.5$ & $76 \pm 1.1$ \\
\hline Air temperature $\left({ }^{\circ} \mathrm{C}\right)$ & \multicolumn{2}{|c|}{$33.8-35.6$} & $33.8-39$ \\
\hline Relative humidity (\%) & \multicolumn{2}{|c|}{$38-45$} & $26-42$ \\
\hline Wind speed (mean, gusts; $\mathrm{km} \cdot \mathrm{h}^{-1}$ ) & \multicolumn{2}{|c|}{7,15} & 15,19 \\
\hline
\end{tabular}

stem. Before the fires, height, canopy diameter, number of stems originating at or below soil surface, stem diameter, and distance from the base of the tagged plant to the base of the nearest shrub in each of four cardinal directions were measured. Height was measured from the ground to the tallest leaf. Canopy diameter was measured at the widest horizontal extent of green leaves and perpendicular to the widest horizontal extent of green leaves. Stem diameter was measured near ground level with a caliper. Within $1 \mathrm{wk}$ before prescribed burns, basal fine fuel load of standing herbaceous matter in a $0.25-\mathrm{m}^{2}$ plot centered on the base of each shrub was ocularly estimated. To avoid removing fine fuel from beneath study plants, a double sampling technique was employed for a random subsample of $30 \%$ of the plants. At these locations, we selected a nearby $0.25-\mathrm{m}^{2}$ plot with similar biomass to clip to ground level. The clipped plot was within $5 \mathrm{~m}$ downwind from the study plant to avoid influencing fire effects on the study plant. Samples were weighed in the field and dried in a forcedair drier at $40-45^{\circ} \mathrm{C}$ until a constant mass was reached to estimate dry mass. Estimated mass values were converted to actual mass with the use of the ratio of actual mass:estimated mass; converted mass values were then converted to dry mass.

\section{Fire Characteristics}

Fuel consumption in each block to be burned was estimated by clipping 10 randomly selected $0.25-\mathrm{m}^{2}$ plots within $1 \mathrm{wk}$ of the fire and after the fire. Fuel load was divided into three categories modified from Masters and Engle (1994): 1) standing and horizontal dry material $\leq 6 \mathrm{~mm}$ in diameter, 2) green herbaceous material, and 3) woody fuel (>6 mm diameter). Preburn and postburn plant material was weighed, dried at $40-45^{\circ} \mathrm{C}$ to a constant mass, and reweighed. Ten maximum registering thermometers were placed on the mineral soil surface and evenly spaced throughout each sampling area to estimate soil surface temperatures. Wind speed at $2.2 \mathrm{~m}$, air temperature, and relative humidity were measured with a digital weather monitor.

Fires were ignited on 13 July 2001 at WWR and 25 August 2001 at RTD. Fires were ignited with the use of a drip torch. Backfires were ignited first, and then flank fires were ignited along fire lines on either side of the area (Fulbright and Ortega-S. 2006). Head fires were ignited after the flank fires were ignited.

\section{Postburn Monitoring}

Shrubs that did not have green leaves or stems $1 \mathrm{yr}$ following the fire were considered dead. Number of sprouts was measured $52 \mathrm{wk}$ postburn and sprout height was measured $47 \mathrm{wk}$ postburn. Plant height, i.e., distance from the ground to the tallest green leaf, was determined $52 \mathrm{wk}$ postburn. If the plant was completely top killed, then sprout height equaled total height. If the plant was not completely top killed, but did produce new basal sprouts, then sprout height was the height of the sprouts and total height was height of the tallest leaf usually originating from plant material that survived the fire. If the plant was not top killed and did not produce new basal sprouts, then only a total height was recorded.

\section{Statistical Analyses}

Analysis of variance for a randomized complete block design and a factorial arrangement of treatments (two burning treatments $\times$ three species) was used to analyze data for the dependent variable percent mortality $52 \mathrm{wk}$ postfire (SAS Institute 1989). Percent mortality was arcsine transformed before analysis. Treatment (fire vs. no fire) and species were independent variables in the analysis. Interactions and main effects were considered significant if $P<0.05$.

Logistic regression was used to examine the relationship between plant survival $52 \mathrm{wk}$ postburn as the dependent variable and plant height, mean canopy diameter, total number of stems, mean diameter of stems, mean distance to neighboring shrubs, and basal fuel load per shrub before fire as independent variables (Kleinbaum and Klein 2002). Logistic regression of plant survival $52 \mathrm{wk}$ postfire was conducted for each species with data pooled across all three blocks.

Stepwise multiple regressions were conducted with the dependent variables sprouts per plant at $52 \mathrm{wk}$, sprout height at $47 \mathrm{wk}$, and total height measured $52 \mathrm{wk}$ postburn using the independent variables height, canopy diameter, number of stems, stem diameter, basal fine fuel, and distance to neighboring shrubs measured before the fires. Regressions were conducted for each species with data pooled from all three blocks.

\section{RESULTS}

Basal fuel load (standing herbaceous matter beneath shrubs) ranged from $1921 \mathrm{~kg} \cdot \mathrm{ha}$ at RTD to $5952 \mathrm{~kg} \cdot \mathrm{ha}$ at WWR1 and relative humidity ranged from $26 \%$ to $45 \%$ at the time of the prescribed burns (Table 1). Weather conditions were similar for the two WWR sites because burns were conducted within $1 \mathrm{~h}$ of each other. Maximum soil surface temperatures 
Table 2. Percent of shrubs $(n=40)$ considered dead (without green leaves or stems) 52 wk postburn for each of three shrub species in two sites burned in July 2001 at the Welder Wildlife Refuge (WWR 1 and WWR 2) and on one site burned August 2001 at the Roche-Thompson Division (RTD) in San Patricio County and Bee County, Texas, respectively.

\begin{tabular}{|c|c|c|c|c|c|c|}
\hline \multirow[b]{3}{*}{ Species } & \multicolumn{6}{|c|}{ Site (Block) } \\
\hline & \multicolumn{2}{|c|}{ WWR 1} & \multicolumn{2}{|c|}{ WWR 2} & \multicolumn{2}{|c|}{ RTD } \\
\hline & Burned & Control & Burned & Control & Burned & Control \\
\hline Huisache (Acacia farnesiana [L.] Willd.) & 0 & 0 & 5 & 3 & 5 & 10 \\
\hline Spiny hackberry (Celtis ehrenbergiana [Klotzsch] Liebm.) & 3 & 0 & 0 & 0 & 13 & 3 \\
\hline
\end{tabular}

during the fires averaged $101 \pm 2{ }^{\circ} \mathrm{C} \quad($ mean $\pm \mathrm{SE} ; n=3)$. Ninety-seven $\pm 2 \% \quad(n=3)$ of fuels $<6 \mathrm{~mm}$ in diameter, $74 \pm 9 \%(n=2)$ of green herbaceous fuel, and $21 \pm 34 \%$ $(n=3)$ of woody fuels were consumed by the fires.

Rainfall at WWR was $120 \mathrm{~mm}$ above the mean (1956-2002) of $1190 \mathrm{~mm}$ during July 2001-September 2002. Precipitation timing and distribution differed between WWR blocks and the RTD block before and after the fires. There was precipitation before the fire at WWR followed by a 1-mo dry period. At RTD the fire was preceded by a dry period and then followed by flooding.

Postfire mortality of brasil ( $26 \pm 21 \%, n=3$ blocks) was greater $(P=0.029)$ on burned sites than on control sites $(1 \pm 1 \%)$. Mortality of huisache and spiny hackberry was similar between burned and control sites $(3 \pm 2 \%$ and $4 \pm 3 \%$, respectively, $P=0.96$ for huisache and $5 \pm 4 \%$ and $1 \pm 1 \%$, respectively, $P=0.48$ for spiny hackberry). Mortality of shrubs varied greatly among sites (blocks; Table 2).

Mortality of spiny hackberry and huisache was so low that examining the relationship between prefire structural characteristics, distance to neighboring shrubs, and basal fine fuel load surrounding the shrub and survival was irrelevant. Distance to neighboring shrubs was the only preburn variable affecting brasil survival retained in stepwise logistic regression analysis. For each 1-m increase in distance to neighboring shrubs there was a 2.45 -fold increase $195 \%$ Wald confidence limits $=1.34-4.49)$ in probability of brasil surviving the fire, $Y=0.00829+(0.8969 \times$ mean distance to nearest shrubs $)$, max-rescaled $R^{2}=0.155, P=0.004$. Brasil plants that survived prescribed burning ranged from $0.3 \mathrm{~m}$ to $5.3 \mathrm{~m}$ from neighboring shrubs, whereas brasil plants killed by fire ranged from $0.01 \mathrm{~m}$ to $3 \mathrm{~m}$ from neighboring shrubs. Mean distance to nearest neighboring shrub varied among sites (blocks) for brasil, with $0.9 \pm 1.0 \mathrm{~m}$ at RTD, the site that experienced the highest postfire mortality, and $1.6 \pm 0.2 \mathrm{~m}$ and $2 \pm 0.2 \mathrm{~m}$, respectively, at the two WWF sites.

Number of sprouts produced following fire increased with increasing number of stems present before fire for all three species (Table 3). Likewise, pretreatment height was consistently positively related to posttreatment height. For brasil, number of sprouts after burning increased with distance to neighbors, but height of sprouts decreased with distance to neighbors. A slight negative relationship existed between postburn height of brasil and preburn stem diameter. Huisache sprout height following fire increased with increasing prefire height. Number of huisache sprouts postburn increased with increasing preburn fine fuel, but postburn plant height declined with increasing preburn fine fuel. Number of spiny hackberry sprouts postburn increased with increasing preburn canopy diameter, and sprout height postburn increased with increasing preburn stem height.

\section{DISCUSSION}

Prefire structural characteristics, position, and basal fine fuel load had no effect on huisache and spiny hackberry survival because mortality following summer fire was similar whether sites were burned or not. Brasil appears to be more susceptible to fire than huisache and spiny hackberry, but none of the variables we measured fully explained why. Similar to our findings for brasil, survival and growth of Santa Barbara Ceanothus (Ceanothus impressus Trel.) seedlings following fire increase with increasing distance to near neighbors (Tyler and D'Antonio 1995). Greater mortality of Santa Barbara Ceanothus seedlings growing in proximity to neighbors was attributed to the resource competition. In our study, the maxrescaled $R^{2}$ value for distance to nearest neighbors was low, indicating that other factors we did not measure explained most of the variation in survival of brasil. Possibly, factors specific to that block other than, or in addition to, shrub density were responsible for high brasil mortality at RTD.

Factors other than the preburn shrub structural characteristics we measured appear to influence postfire shrub survival most strongly; whereas these characteristics are useful in predicting postfire recovery (vigor). Effects of prescribed burning on mortality of individual plant species appear highly variable, based on our results and results of other researchers (Box et al. 1967; Owens et al. 2002; Ruthven et al. 2003). The high mortality of brasil in one experimental unit in our study indicates the possibility exists for warm-season fires to cause changes in woody plant species composition.

The high variation in mortality of brasil among blocks is interesting because it is desirable for land managers to be able to predict postfire mortality, particularly of shrubs valuable as food and cover for wildlife. Reasons for this high variation are unclear. Higher fuel loads are associated with increased fire damage to woody plants (Britton and Wright 1971; Van Langevelde et al. 2003; Thaxton and Platt 2006); however, standing herbaceous fuel loads were lower at RTD than on the blocks at WWR. Reduced postfire survival of sprouting shrubs has been associated with greater fuel consumption (Kauffman and Martin 1989); however; consumption of dry fuels $<6 \mathrm{~mm}$ in diameter was lower at RTD (93\%) than at WWR $199 \%$ for both blocks). Maximum soil surface temperatures reached during the fires were relatively low and it is unlikely that 
Table 3. Multiple linear regression relationships between the dependent variables number of sprouts per plant, and total height ( $\mathrm{m}) 52 \mathrm{wk}$ postfire and sprout height $(\mathrm{m}) 47$ wk postfire, and the prefire characteristics shrub height $(\mathrm{m})$, canopy diameter $(\mathrm{m})$, mean stem diameter (mm), number of stems per shrub, distance to neighboring shrubs $(\mathrm{m})$, and basal fine fuel load $\left(\mathrm{g} \cdot 0.25 \mathrm{~m}^{-2}\right)$ for brasil (Condalia hookeri M. C. Johnst.), huisache (Acacia farnesiana [L.] Willd.), and spiny hackberry (Celtis ehrenbergiana [Klotzsch] Liebm.) shrubs burned during July and August 2001, San Patricio County and Bee County, Texas.

\begin{tabular}{|c|c|c|c|c|c|c|c|c|c|c|c|}
\hline Species & $\begin{array}{c}\text { Weeks } \\
\text { postburn }\end{array}$ & $\begin{array}{l}\text { Source of } \\
\text { variation }\end{array}$ & $d f$ & $\mathrm{MS}^{1}$ & $F$ & $P$ & $R^{2}$ & Variable & Coefficient & $F$ & $P$ \\
\hline \multicolumn{12}{|l|}{ Number of sprouts } \\
\hline \multirow[t]{3}{*}{ Brasil } & 52 & Model & 2 & 2143.1 & 10.1 & $<0.001$ & 0.15 & Intercept & 1.85 & 0.51 & 0.475 \\
\hline & & Error & 116 & 213.2 & & & & Distance to neighbors & 2.9 & 6.87 & 0.01 \\
\hline & & & & & & & & No. stems & 1.44 & 14.58 & $<0.001$ \\
\hline \multirow[t]{4}{*}{ Huisache } & 52 & Model & 3 & 2106.9 & 35.4 & $<0.001$ & 0.48 & Intercept & -6.08 & 6.53 & 0.012 \\
\hline & & Error & 116 & 54.5 & & & & Height & 6.0 & 19.57 & $<0.001$ \\
\hline & & & & & & & & Fine fuel load & 0.003 & 13.23 & $<0.001$ \\
\hline & & & & & & & & No. stems & 1.55 & 16.45 & $<0.001$ \\
\hline \multirow[t]{3}{*}{ Spiny hackberry } & 52 & Model & 2 & 1447.8 & 15.2 & $<0.001$ & 0.21 & Intercept & 4.4 & 3.9 & 0.051 \\
\hline & & Error & 117 & 95.4 & & & & Canopy diameter & 4.32 & 7.37 & 0.008 \\
\hline & & & & & & & & No. stems & 1.26 & 19.01 & $<0.001$ \\
\hline \multicolumn{12}{|l|}{ Sprout height } \\
\hline \multirow[t]{2}{*}{ Brasil } & 47 & Model & 1 & 0.11 & 4.88 & 0.03 & 0.06 & Intercept & 0.37 & 167.45 & $<0.001$ \\
\hline & & Error & 76 & 0.02 & & & & Distance to shrubs & -0.03 & 4.88 & 0.03 \\
\hline \multirow[t]{2}{*}{ Huisache } & 47 & Model & 1 & 2.8 & 39.58 & $<0.001$ & 0.26 & Intercept & 0.49 & 37.23 & $<0.001$ \\
\hline & & Error & 111 & 0.07 & & & & Height & 0.25 & 39.58 & $<0.001$ \\
\hline \multirow[t]{2}{*}{ Spiny hackberry } & 47 & Model & 1 & 2.24 & 30.66 & $<0.001$ & 0.22 & Intercept & 0.2 & 11.43 & 0.001 \\
\hline & & Error & 108 & 0.07 & & & & Height & 0.23 & 30.66 & $<0.001$ \\
\hline \multicolumn{12}{|l|}{ Total height } \\
\hline \multirow[t]{3}{*}{ Brasil } & 52 & Model & 2 & 9.2 & 40.7 & $<0.001$ & 0.49 & Intercept & -0.44 & 11.34 & 0.001 \\
\hline & & Error & 85 & 0.2 & & & & Height & 0.84 & 77.51 & $<0.001$ \\
\hline & & & & & & & & Stem diameter & -0.003 & 4.73 & 0.033 \\
\hline \multirow[t]{3}{*}{ Huisache } & 52 & Model & 2 & 8.0 & 33.4 & $<0.001$ & 0.37 & Intercept & 0.42 & 15.59 & $<0.001$ \\
\hline & & Error & 113 & 13.5 & & & & Height & 0.44 & 66.35 & $<0.001$ \\
\hline & & & & & & & & Fine fuel load & -0.0001 & 7.40 & 0.008 \\
\hline \multirow[t]{2}{*}{ Spiny hackberry } & 52 & Model & 1 & 9.9 & 71.3 & $<0.001$ & 0.39 & Intercept & 0.04 & 0.20 & 0.653 \\
\hline & & Error & 112 & 0.1 & & & & Height & 0.46 & 71.34 & $<0.001$ \\
\hline
\end{tabular}

${ }^{1}$ Mean square.

differences among blocks in soil surface temperatures affected mortality of brasil. Mortality of 3.5-yr-old mesquite, also a sprouting shrub, was only $8 \%$ following fires with maximum soil surface temperatures ranging from $93^{\circ} \mathrm{C}$ to $260^{\circ} \mathrm{C}$ (Wright and Bailey 1982). Additional data on fire intensity and characteristics may have helped to clarify these results; however, these are difficult to quantify in large-scale fires ( $\geq 202 \mathrm{ha}$ ), such as in our study.

Other possible reasons for the wide range in mortality between blocks on WWR and RTD include differences in weather conditions at burning and differences in historical disturbance regimes among blocks. Burns at WWR were preceded by a small amount of precipitation $(45 \mathrm{~mm})$ and followed by a 6-wk dry period, then flooding. Burns at RTD were preceded by the 6 -wk dry period, and then the block was burned and flooded within $24 \mathrm{~h}$. August precipitation during the period immediately after the RTD burn until the end of the month was $289 \mathrm{~mm}$ at the RTD (recorded about $16 \mathrm{~km}$ southwest of the RTD) and $196 \mathrm{~mm}$ at WWR (WWR Records 2001, unpublished; Texas AgriLife Research and Extension Center at Corpus Christi 2008). These totals are much greater than the August historical average rainfall of $86 \mathrm{~mm}$ (19562002; WWR Records 2002, unpublished). Soil at RTD appeared saturated for the first $6 \mathrm{wk}$ postfire. Possibly, fire immediately followed by a flood imposed additional stress on brasil at RTD, resulting in greater mortality than at WWR, where no flooding occurred following the burns. The unique combination of these two events causing mortality and not the flooding alone is evident due to the fact that similar mortality was not observed in the equally flooded control site at RTD. Interestingly, brasil was the only one of the three species with greater mortality at RTD, suggesting additional characteristics or properties specific to brasil must be involved in the explanation for increased mortality of brasil at RTD.

Land-use history has greater impacts on vegetation than fire intensity in the tall grass prairies of Oklahoma (Engle et al. 2000). Land-use history differed between WWR and RTD. Blocks on WWR were burned during January 1996 and were deferred from livestock grazing for 7 mo longer before fires than RTD, and were not grazed during the study. Blocks on WWR have not been mechanically manipulated to control woody plants. Chaining on RTD in 1990 possibly altered 
woody plant community structure. Chaining reduces shrub densities for a few years, but long-term effects of chaining can include declines in plant species diversity, increased woody plant density, and reduced landscape heterogeneity (Scifres et al. 1976; Nolte et al. 1994). As shown, mean distance to neighboring shrubs was less at RTD, yet it yielded higher mortality.

Greater fine fuel loads were associated with increased postfire sprouts and less height growth in huisache. Apparently, huisache compensated for additional plant damage resulting from greater fuel loads by allocating more resources to sprout production, thereby making a tradeoff between height growth and spout production. In a similar manner, velvet mesquite (Prosopis velutina Woot.) compensates for branch growth lost from severe burns through increased sprout production (Bock et al. 2007). Our results differed from other studies in which higher fuel loads were associated with increased fire damage to woody plants (Britton and Wright 1971; Van Langevelde et al. 2003; Thaxton and Platt 2006).

Much of the Texas gulf prairies and marshes and south Texas plains have changed from pre-Columbian prairies into a contemporary landscape consisting of thorn-shrub clusters interspersed within a grassland matrix (Archer et al. 1988). Spiny hackberry and brasil become established in the process of shrub cluster development at the same time in roughly equal probability in the chronology of shrub invasion presented by Archer et al. (1988). Huisache becomes established in habitats dominated by herbaceous vegetation and does not occur in shrub clusters. Distance to neighboring shrubs was the significant factor affecting postfire survival for brasil. By establishing in later stages of shrub cluster development, brasil usually occurs in shrub clusters where it is protected from fire by surrounding shrubs. Perhaps becoming established in later stages of cluster development allows brasil to avoid fire and represents an adaptation to an ecosystem that evolved with a high frequency of fire (Frost 1998). Brasil may be less adapted to withstand fire than huisache because of its habit of establishing within the protection of shrub clusters, whereas huisache apparently is adapted to withstand intense fires in herbaceous-plant-dominated sites.

Spiny hackberry becomes established in shrub clusters at the same time as brasil, but did not experience high mortality in our study. Possibly, spiny hackberry has some resistance trait such as bark properties that make it more fire resistant than brasil. Gignoux et al. (1997) used postfire recovery to index fire resistance in contrast to our approach in which factors influencing mortality and recovery were considered separately. We considered shrubs with the greatest sprout production and height and greater total shrub height $1 \mathrm{yr}$ postburn to have shown the greatest recovery from fire. Our results agree with conclusions of Gignoux et al. (1997) that vigor (recovery after fire) was affected by more characteristics than trunk thickness.

Hodgkinson (1998) reported that percent of the population that sprouted following fire increased with increasing height and bark thickness up to a critical level. The critical levels of height and bark thickness varied among shrub species. Beyond the critical levels, shrub survival either remained the same or declined. Our results agree with Hodgkinson (1998) because recovery height after fire was positively related to preburn height. Control of fires to frequencies longer than the historic 1-3-yr interval may have allowed previously low-stature shrubs to grow to heights above herbaceous communities (Johnston 1963; Frost 1998). Our results indicate shrubs allowed to grow during long fire-free intervals are better at recovery postfire.

\section{MANAGEMENT IMPLICATIONS}

Larger shrubs are more likely to survive fire and grow back well; therefore, burning when plants are shorter, e.g., repeating burns at more frequent intervals, may retard postburn growth and may be more effective at maintaining suppression of brush. Burning shrubs during summer stimulates new regrowth that is preferred by deer over browse on mature plants (Schindler et al. 2004). Deer concentrate feeding activities in patches with immature browse during summer (Stewart et al. 2000). Energy is commonly deficient in white-tailed deer forages during summer throughout much of the range of the species and stimulating nutritious regrowth with fire may be a management strategy to improve white-tailed deer nutrition (Meyer et al. 1984; Rose and Harder 1985). Possible loss of shrubs desirable for wildlife, such as occurred for brasil in our study, should be weighed against benefits derived from burning.

\section{ACKNOWLEDGMENTS}

The Welder Wildlife Refuge and McFaddin Enterprises, Ltd. provided access to their land. The authors thank P. Ortega-S. and D. Drawe for reviewing early drafts of this manuscript. This is Caesar Kleberg Wildlife Research Institute Manuscript 08-116 and Rob and Bessie Welder Wildlife Foundation Contribution 681.

\section{LITERATURE CITED}

Abella, S. R., And P. Z. Fulé. 2008. Fire effects on Gamble oak in Southwestern ponderosa pine-0ak forests. Washington, DC, USA: US Department of Agriculture, Forest Service. Research Note RMRS-RN-34. 6 p.

Ansley, R. J., And C. A. Taylor. 2004. What's next: the future of fire as a tool for managing brush. In: W. T. Hamilton, A. McGinty, D. N. Ueckert, C. W. Hanselka, and M. R. Lee [EDS.]. Brush management: past, present, and future. College Station, TX, USA: Texas A\&M University Press. p. 200-210.

Archer, S., C. Scifres, C. R. Bassham, and R. Maggio. 1988. Autogenic succession in a subtropical savanna: conversion of grassland to thorn woodland. Ecological Monographs 58:111-127.

Bock, C. E., L. Kennedy, J. H. Bock, And Z. F. Jones. 2007. Effects of fire frequency and intensity on velvet mesquite in an Arizona grassland. Rangeland Ecology and Management 60:508-514.

Bond, W. J., AND J. J. Midgley. 2001. Ecology of sprouting in woody plants: the persistence niche. Trends in Ecology and Evolution 16:45-51.

Box, T. W., J. Powell, and D. L. Drawe. 1967. Influence of fire on south Texas chaparral communities. Ecology 48:955-961.

Britton, C. M., And H. E. Wright. 1971. Correlation of weather and fuel variables to mesquite damage by fire. Journal of Range Management 24:136-141.

Drawe, D. L., A. D. Chamrad, and T. W. Box. 1978. Plant communities of the Welder Wildlife Refuge. Sinton, TX, USA: Rob and Bessie Welder Wildlife Foundation. Contribution No 5, Series B. 42 p.

Drewa, P. B., W. J. Platt, and E. B. Moser. 2002. Fire effects on resprouting of shrubs in headwaters of southeastern longleaf pine savannas. Ecology 83:755-767.

Engle, D. M., M. W. Palmer, J. S. Crockett, R. L. Mitchell, and R. Stevens. 2000. Influence of late season fire on early successional vegetation of an Oklahoma prairie. Journal of Vegetation Science 11:135-144. 
Flinn, M. A., And R. W. Wein. 1977. Depth of underground plant organs and theoretical survival during fire. Canadian Journal of Botany 55:2550-2554.

Flinn, R. C., C. J. ScIFres, And S. R. Archer. 1992. Variation in basal sprouting in cooccurring shrubs: implications for stand dynamics. Journal of Vegetation Science 3:125-128.

Frost, C. 1998. Presettlement fire frequency regimes of the United States: a first approximation. In: T. L. Pruden and L. A. Brennan [EDs.]. Fire in ecosystem management: shifting the paradigm from suppression to prescription. Tall Timbers Fire Ecology Conference Proceedings, No. 20. Tallahassee, FL, USA: Tall Timbers Research Station. p. 70-81.

FulbRiGHt, T. E. 2001. Human-induced vegetation changes in the Tamaulipan scrub of La Frontera. In: L. G. Webster and C. J. Bahre [EDS.]. Changing plant life of La Frontera. Albuquerque, NM, USA: University of New Mexico Press. p. 166-175.

Fulbright, T. E., and J. A. Ortega-S. 2006. White-tailed deer habitat: ecology and management on rangelands. College Station, TX, USA: Texas A\&M University Press. $241 \mathrm{p}$.

Gignoux, J., J. Clobert, and J. Menaut. 1997. Alternative fire resistance strategies in savanna trees. Oecologia 110:576-583.

HodGkinson, K. C. 1998. Sprouting success of shrubs after fire: height-dependent relationships for different strategies. Oecologia 115:64-72.

Johnston, M. C. 1963. Past and present grasslands of southern Texas and northeastern Mexico. Ecology 44:456-466.

Kauffman, J. B., and R. E. Martin. 1989. Sprouting shrub response to different seasons and fuel consumption levels of prescribed fire in Sierra Nevada mixed conifer ecosystems. Forest Science 36:748-764.

KLeinBaum, D. G., AND M. KLeIN. 2002. Logistic regression: a self-learning text. 2nd ed. New York, NY, USA: Springer Science + Business Media. 513 p.

Konstantinidis, P., G. Tsiourlis, and S. Galatsidas. 2005. Effects of wildfire season on the resprouting of kermes oak (Quercus coccifera L.). Forest Ecology and Management 208:15-27.

Masters, R. E., and D. M. Engle. 1994. BeHAVE-evaluated for prescribed fire planning in mountainous oak-shortleaf pine habitats. Wildlife Society Bulletin 22:184-191.

McLendon, T. 1991. Preliminary description of the vegetation of South Texas exclusive of coastal saline zones. Texas Journal of Science 43:13-32.

Meyer, M. W., R. D. Brown, and M. W. Graham. 1984. Protein and energy content of white-tailed deer diets in the Texas Coastal Bend. Journal of Wildlife Management 48:527-534.

Nolte, K. R., T. M. Gabor, M. W. Hehman, M. A. Asleson, T. E. Fulbright, and J. C. Rutledge. 1994. Long-term effects of brush management on vegetation diversity in ephemeral drainages. Journal of Range Management 47:457-459.

Owens, M. K., J. W. Mackley, and C. J. Carroll. 2002. Vegetation dynamics following seasonal fires in mixed mesquite/acacia savannas. Journal of Range Management 55:509-516.

Pausas, J. G., R. A. Bradstock, D. A. Keith, J. E. Keeley, and the Global Change of Terrestrial Ecosystems Fire Network. 2004. Plant functional traits in relation to fire in crown-fire ecosystems. Ecology 85:1085-1100.
Rasmussen, G. A., C. J. Scifres, and D. L. Drawe. 1983. Huisache growth, browse quality, and use following burning. Journal of Range Management 36:337-342.

RoSE, J., AND J. D. HARDER. 1985. Seasonal feeding habits of an enclosed whitetailed deer herd in northern Ohio. Ohio Journal of Science 85:184-190.

Ruthven, D. C. III, A. W. Braden, H. J. Knutson, J. F. Gallagher, and D. R. Synatske. 2003. Woody vegetation response to various burning regimes in South Texas. Journal of Range Management 56:159-166.

SAS InstituTE, Inc. 1989. SAS user's guide: statistics. Cary, NC, USA: SAS Institute, Inc. $445 \mathrm{p}$.

Schindler, J. R., T. E. Fulbight, and T. D. A. Forbes. 2004. Shrub regrowth, antiherbivore defenses, and nutritional value following fire. Journal of Range Management 57:178-186.

ScIFRES, C. J. 1980. Brush management: principles and practices for Texas and the Southwest. College Station, TX, USA: Texas A\&M University Press. $360 \mathrm{p}$.

Scifres, C. J., J. L. Mutz, And G. P. Durham. 1976. Range improvement following chaining of south Texas mixed brush. Journal of Range Management 29:418-421.

Soll Survey Staff, natural Resources Conservation Service, uS Department of Agriculture. 2008. Official soil series descriptions. Available at: http://soils. usda.gov/technical/classification/. Accessed 30 April 2008.

Sparks, J. C., R. E. Masters, D. M. Engle, and G. A. Bukenhofer. 2002. Season of burn influences fire behavior and fuel consumption in restored shortleaf pinegrassland communities. Restoration Ecology 10:714-722.

Stewart, K. M., T. E. Fulbright, and D. L. Drawe. 2000. White-tailed deer use of clearings relative to forage availability. Journal of Wildlife Management 64:733-741.

TAYLOR, C. A. 2007. Role of summer prescribed fire to manage shrub-invaded grasslands. In: R. E. Sosebee, D. B. Wester, C. M. Britton, E. D. McArthur, and S. G. Kitchen [Comps.]. Proceedings: shrubland dynamics-fire and water; 10-12 August 2004. Lubbock, TX, USA: US Department of Agriculture, Forest Service. RMRS-P-47. p. 52-55.

Texas AgriLife Research and Extension Center at Corpus Christi. 2008. Crop Weather Program. Available at: http://cwp.tamu.edu/. Accessed 21 July 2008.

Thaxton, J. M., And W. J. Platt. 2006. Small-scale fuel variation alters fire intensity and shrub abundance in a pine savannah. Ecology 87:1331-1337.

TyleR, C. M., AND C. M. D'Antonio. 1995. The effects of neighbors on the growth and survival of shrub seedlings following fire. Oecologia 102:255-264.

us Department of Agriculture, Natural Resources Conservation Services. 2008. The PLANTS database. Available at: http://plants.usda.gov. Accessed 21 July 2008.

Van Auken, 0. W. 2000. Shrub invasions of semiarid North American grasslands. Annual Review of Ecology and Systematics 31:197-215.

Van Langevelde, F., C. A. D. M. Van De Vijver, L. Kumar, J. Van De Koppel, N. De Ridder, J. Van Andel, A. K. Skidmore, J. W. Hearne, L. Stroosnijder, W. J. Bond, H. H. T. Prins, and M. Rietkerk. 2003. Effects of fire and herbivory on the stability of savanna ecosystems. Ecology 84:337-350.

Wright, H. A., and A. W. Bailey. 1982. Fire ecology: United States and southern Canada. New York, NY, USA: Wiley Interscience. 501 p. 